\author{
Lazaros E. MAVROMATIDIS \\ Asimina MAVROMATIDI
}

\title{
Reinventing the doubt of the icon: A virtual case study in a post-Soviet country's capital
}

The main objective of this paper is to define, negotiate and debate radical socio-cultural approaches of landscape creation in today's megacities, within a strict capitalist context. For this reason, it investigates both the theoretical and concrete manner of the spatial expression within an imposed contemporary Foucauldian state of disciplines. Therefore, the research methodology simultaneously develops two different hypotheses in order to bridge the gap between the theoretical explorations and concrete dimension of architectural creation. The primary hypothesis is based on the Lacanian dimension of doubt that is considered in this work as the Chomskyan primitive power that gives birth to every idea or concept, having the potential to exasperate the radical imaginary of each society such as it is defined in Castoriadis' writings. The second main hypothesis is based on an analytical exploration of space creation within strict political and economical contexts. For this purpose, a post-Soviet country served as a case study in order to investigate the cultural landscape values in both communist and capitalist regimes. Hence, focusing on Armenia and especially on Yerevan's landscape transformations during the transition from communism to capitalism, this article first departs from the need to employ a deep theoretical analysis of non-economic factors in order to guide capitalist societies through cooperation with the disadvantaged social structure that has no space in today's megacities and, second, details an original landscape creation sketched by a real recent architectural competition that is seen here as a contemporary Foucauldian state of disciplines. The main object of the architectural composition presented in this contribution is to fulfil the competitions' guidelines having in mind, however, consolidation of the imposed image of global capitalism with local elements in order to form a Foucauldian heterotopia by allowing different socio-cultural identities to debate, contest or doubt the proposed iconic spatial expression. The article offers a new approach regarding the notion of doubt seen here as a positive element of architectural practice by proposing its continuous existence in the conceptual dimension of architecture.

Key words: doubt, cultural landscape, virtual landscape, rescaling, radical imaginary, Yerevan, Armenia 


\section{Introduction}

This contribution first of all investigates the degree to which architectural procedures have doubted the Foucauldian state of disciplines of each historical period. In addition, we articulate that this state of disciplines that characterises each historical period guides society to produce the necessary symbols through architecture in order to identify itself through time. Thereby, the economic and political organisation of societies throughout human history have guided architecture to eliminate the substantial doubt associated with primitive architectural action. Hence, our main intention is to reposition architecture in a contemporary framework by regenerating the notion of doubt in its conceptual dimension. Thus, considering Maria Kaikàs (2011) spatial interpretation of radical imaginary based on Cornelius Castoriadis' definition, we seek to understand and evaluate the influence of new reconceptualisation patterns on the production of urban space and landscape, as demanded by transnational decision centres and institutions.

Choosing Yerevan as the territory of study and always having in mind the Soviet era of this capital, by also focusing on the post-Soviet period this article explores how space production was oriented to organise social life in order to serve the dominating interests of each historical period through official or unofficial state planning. It mainly studies how the transition from the Soviet system to a liberal capitalist system can influence the cultural landscape of a city by creating virtual landscape images (Mavromatidis, 2010) in order to obtain favourable publicity in the contemporary context of globalisation. The effort of virtual architectural creation presented in this contribution aims to enrich the debate on how cultural professionals and architects or urban planners can contribute to the "production of locality and the symbolic construction of categories such as the 'global' and the 'local' in times of social change" (Molnar, 2011: 283) and economic crisis. In an attempt to attract national or transnational investors, the creation of a new virtual landscape (Mavromatidis, 2010) city image has become the central concern, and architects are increasingly acting as producers of such images, acting as objects of decision-making.

Today, the ultimate contemporary tool of unofficial state planning is international architectural competitions, which illustrate and demonstrate how "expertise translates into political power despite architects' lack of control over tangible political and economic resources" (Molnar, 2011: 285) or how, during periods of crisis, architecture teaches society "what to desire and how to desire it" (Žižek, 1989, cited in Kaika, 2010: 458) by acting as part of the radical imaginary in Castoriadis' conceptualisation (Kaika, 2010). This contribution deals with the effort of an original creation that aims to create a network of doubts regarding whether - through a series of architectural competitions and building projects, which may tackle the cultural dimension of various historical layers - it is possible to construct a model of space production having as its main object the consolidation of the imposed image of global capitalism with local elements, in order to form a heterotopia (Foucault, 1993).

Finally, in order to avoid a failed theorisation of the non-economic factors of this case study and a fuzzy theoretical conceptualisation and spatial analysis, this research has empirical support. Following Kaika's methodological approach (2010) in order to expand the critical framework within which we can examine the production of architecture, the people that live in the architectural space being studied are invited to offer their opinions as important actors and research subjects; this includes architects, planners and decision makers. This research comprised 200 five-minute anonymous telephone interviews with a randomly selected sample of Yerevan's inhabitants (100 females, 100 males). The empirical study focused first of all on public perceptions of the notion of doubt (Rus. сомнения) and, second, on the controversy around the production of Yerevan's new virtual landscape (Rus. виртуальный randuaøm) image. ${ }^{[1]}$ Although the list of interviewees is not exhaustive, we believe that this part of the research is extremely important because several dimensions of Yerevan's reality have been investigated in order to obtain the point of view of people that have mostly (60\% of the interviewees) lived in the two different economic organisational systems of the last century.

\section{The action of creation}

\author{
You are a bird of heaven; \\ you live inside my skull \\ my brain nourishes you \\ and only for that reason you exist. \\ (Hionis, 2010: 39 [authors' translation])
}

Even if it is culturally accepted today that the human mind gives birth to and nourishes thoughts, ideas and concepts, at the same time it is very difficult to identify the primordial power that motivates human nature to accomplish an action of creation. In philosophy this power could be considered both internal and external (for details, see Foucault-Chomsky, $1974^{[2]}$ ). On the one hand, according to Chomsky, there exists an instinctive knowledge or formation that permits to an individual person to derive a complex awareness from partial information and this substantial knowledge is a fundamental component of human nature. On the other hand, Foucault, mistrusting the notion of human nature, considers the principal power to be external and that the problem of creativity can be formulated by having in mind the state of disciplines into which it is put. 
Even if someone does not mistrust the notion of human nature, he cannot deny that built architectural concepts reveal an almost erotic relationship between architecture and the economic-political context. Furthermore, Kaika (2011) based on Castoriadis' reflection, developed the opinion that each society across time constructed its iconic architectural objects and these objects "functioned across history as totems of a particular social order, as part of a system of significations that define the collectivity of this society" (Castoriadis, 1987, cited in Kaika, 2011: 972). What is commonly known as collective identity is not an independent entity but is a non-economic structure born within a certain economic framework where "economic activity is socially, culturally and institutionally situated" (Hadjimichalis, 2006: 692). By accepting that architecture is the spatial formulation of collective identity, one could claim that this erotic relation between the economic-political interests of each historical period and space production gave birth to a new definition of planning a notion by dissociating it from architecture. According to Norman and Susan Fainstein's (1985: 492) definition, "planning is a form of decision making which self-consciously explicates its own logic, usually in technical terms; attempts to anticipate changes in an organisational environment; and establishes long-range policies designed to optimise the attainment of organizational objectives".

In order to further understand how this separation happened, recall that during human history the economic-political organisation of societies aimed to put rules into human behaviour and control human nature, and especially the intellectual dimension of doubt, by constructing a network of religious, ethical, economic, political and cultural certainties. If one considers that architecture is first of all the human ability to form shelter from external conditions, one could state that architecture was born from a primitive doubt due to its artistic dimension regarding the aesthetic and utilitarian adequacy of existing natural forms. From the Fainsteins' definition and bearing in mind that the nature of architecture is based on continuous doubt of the spatial forms that enclose the human dimension, it can be concluded that planning is the negative of architecture in the way that a decision is the negative of doubt. In a concrete way, one can say that the purpose of architecture is to find the correct spatial questions; however, planning is oriented to provide specific answers and solutions.

Moreover, at a social organisation level, architecture was driven to lose the intellectual status of doubt through the creation of this Foucauldian state of disciplines that aimed to organise social life in a rational way and serve the dominating interests of each historical period through official or unofficial state planning (for further development, see also Davidoff, 1965; Gans, 1968; Castells, 1977, 1978, 1996; Harloe, 1977; Harvey, 1978; Stone \& Harpham, 1982; Holton, 1984; Fainstein \& Fain- stein, 1985; Sklair, 2005; Hadjimichalis \& Hudson, 2006). Being transformed into a decision-making practice, architecture loses this dimension of doubt as such, "the uncertainty, the open state where everything is still possible, where none of the options are precluded" (Žižek, 1998: 75).[3]

\section{Yerevan's landscape and the transition from communism to capitalism}

After this brief analysis of the literature regarding the action of creation, we focus on analysing the special features of the territory under study. In this contribution, architecture is seen as an intermediate discipline, in which the architect should combine philosophical and sociological knowledge in order to create space and not building envelopes. Located along the Hrazdan River, Yerevan has always been the industrial, cultural and administrative centre of Armenia since 1918 and especially when "thousands of survivors of the Armenian Genocide settled in this area" (Katsenelinboigen 1990: 78). Throughout Armenian history, Yerevan's social, cultural and economic leadership has had an extensive influence on the entire country. In recent years, the growth of the economy of the country has changed Yerevan's landscape image because many parts of the city have seen new construction since the early 2000s. Yerevan was the first city in the Soviet Union for which a general plan was developed. During the Soviet era, the city became a significant scientific and cultural centre, being transformed into a modern industrial metropolis of over a million people. Alexander Tamanyan designed Soviet Yerevan by trying to incorporate national traditions with Soviet urban and landscape creation (Figure 1). As a result, many traces of the past and historic buildings such as the Persian fortress, churches, mosques, caravanserais, bazaars and baths were sacrificed and demolished in order to create an ideal Soviet city.

According to Ivan Szelenyi (1984), in practice all communist countries seem to enter a stage of unnatural growth in which their industrialisation happens at a faster rate than in many capitalist economies at the same level of economic development. Furthermore, according to Laszlo Kulcsar and Tamas Domokos (2005), in order to homogenise spatial and social structures, communist development insisted on eliminating inherited inequalities through state planning and this is why the search for local identity and local organisation was strongly discouraged. Employing these arguments can explain in theory why the ancient cultural landscape of a city with an extensive history was not respected in order to politically and culturally enforce the city's leadership in the new Soviet region. This fact reveals the opinion that the territorial planning is necessarily related to urban planning and significantly affects the cultural 


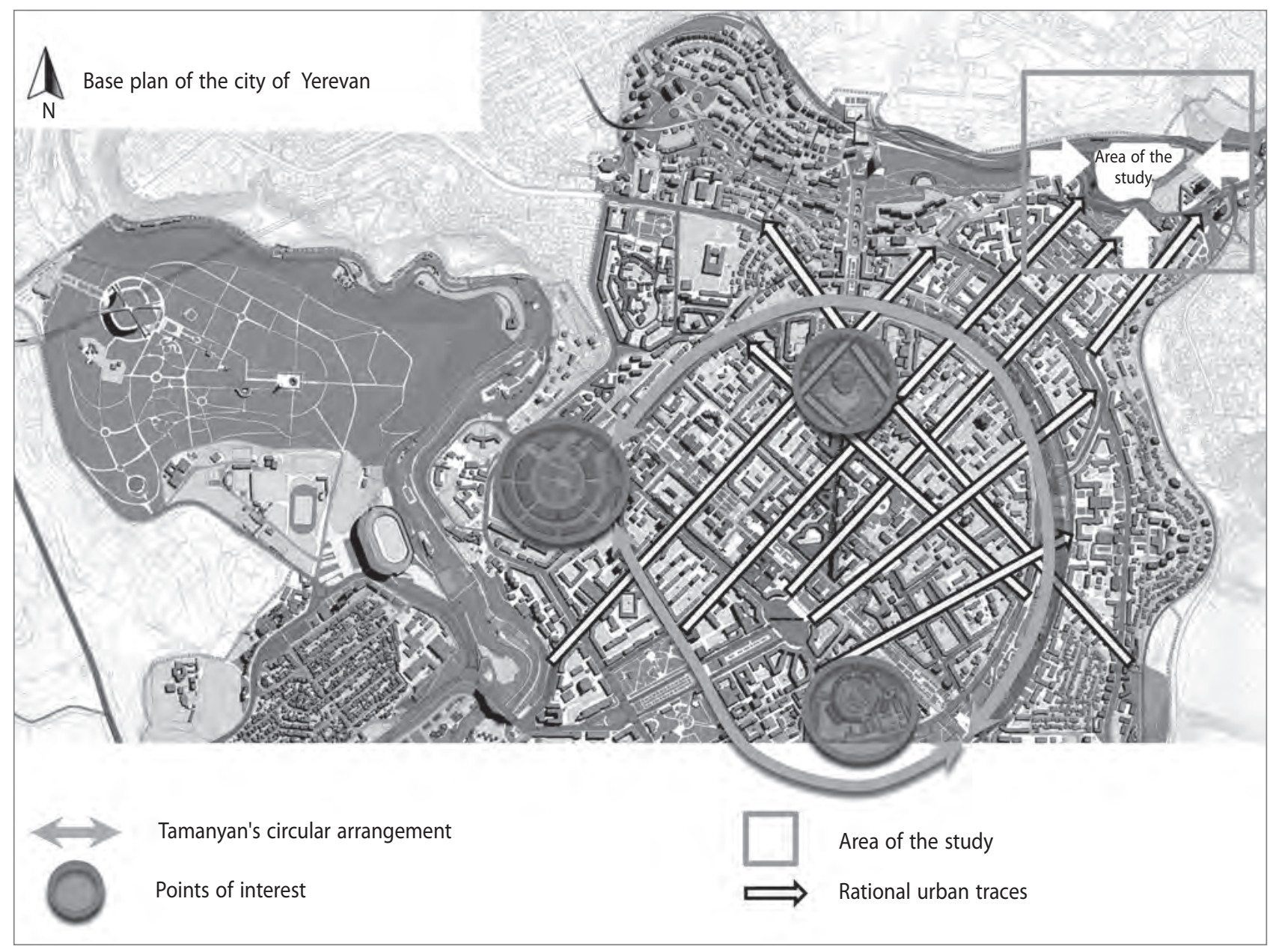

Figure 1: Analysis of the base plan of the central district of Yerevan. It shows the circular arrangement of Tamanyan's plan. The territory of this design study is in the northeast part of the plan (illustration: Hanna Mangasarian \& Lazaros E. Mavromatidis).

landscape by focusing on land use (Mavromatidis, 2010). Even if this huge urban plan managed to expand the city's image in the Soviet world, at the same time it transformed the place into a sort of neutral space for the inhabitants of the Armenian capital because the fundamental logic of central communist development considered any efforts at self-organisation to be a threat to the political system (Kulcsar \& Domokos, 2005).

It is important to recall that David Canter (1977) maintains that to understand a place one must know both the conceptions and meanings that people associate with the setting and the physical characteristics and features of the space. The empirical data confirmed this opinion because almost in their totality the interviewees associated the notion of sense of place with nostalgia for childhood memories such as parental home (Rus. родительский дом), parental yard (Rus. родительский двор) or native land (Rus. poduнa). In theory, when the character of a small city is threatened as a result of the loss of meaningful environmental features, the community's sense of attachment, continuity and permanence with the constructed and natural environment could also be lost (Brown \& Perkins, 1992). This fact also proves that the industrialisation of the communist era had an influence on the psychology of the people by transferring populations from the countryside to the industrial city centres, creating with the passage of the time nostalgia for the rural lifestyle through childhood memories.

In any event, in Yerevan's case, even if this connection with the past had been lost, another connection with a common Soviet denominator was created by preserving an imposed community's sense of attachment. In Soviet Armenia, the system of values promoted the organisation of social life within a community network. The new era in the city turned into an image of the numerous infrastructures that the central government imported into the new urban plan such as museums, industries and large-scale residential apartment blocks assimilated with huge squares and urban connections (Figure 2). It is important to recall here that this kind of rescaling that happened during Yerevan's Soviet period implied not only the rescaling of urban space, but the cultural landscape as well.

Yerevan became the capital of the Republic of Armenia in 1991, following the dismantling of the USSR. However, the newly born Republic of Armenia could not economically 

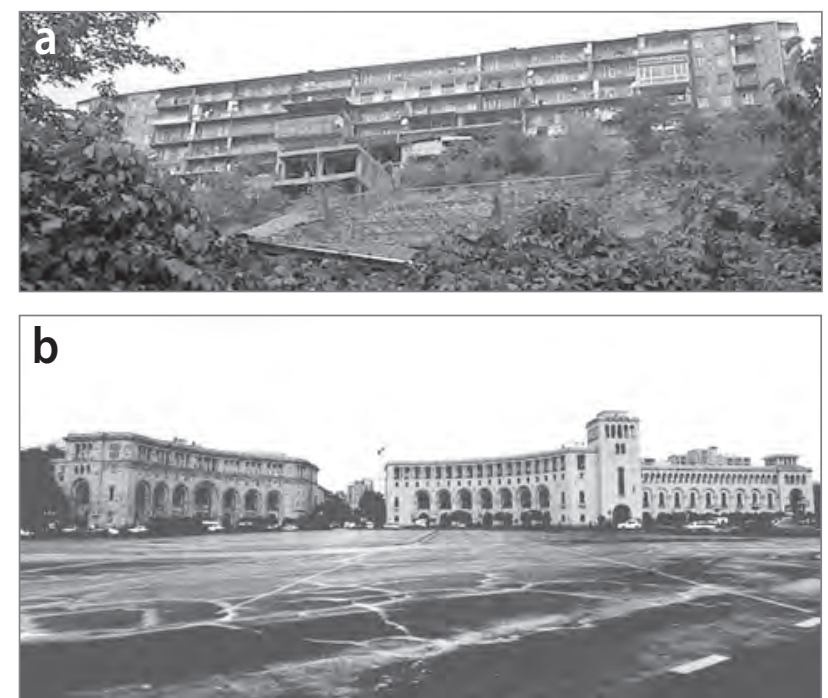

Figure 2: a) Communal apartments in Yerevan form a cultural landscape as a result of the city's restructuring during the Soviet era; b) Public buildings and public spaces directly show the power of the regime through the cultural landscape that they form. Republic Square was named Lenin Square and featured a giant Lenin statue during the Soviet period. To the right is the building of the Foreign Affairs and the Energy ministries, and to the left Hotel Armenia, which was the most luxurious hotel in Yerevan during the Soviet era (photos: Hanna Mangasarian).

afford to maintain electricity and gas supplies. This created a poor image for the capital of Armenia and the Armenian economy worldwide. According to Harvey Molotch (1996: 229) "the positive connection of product image to place yields a kind of monopoly rent that adheres to places, their insignia, and the brand names that may attach to them." In marketing-communication terms, images play an important marketing role in the creation of a virtual landscape within a globalised context (Mavromatidis, 2010) because they affect perceptions and various spatial decisions made by three different groups according to Eli Avraham (2000): the general public, decision-makers at a national and international level, and the place's inhabitants.

Because of the badly planned and implemented transition to a market-based economy, the image of an economically weak country was created the first years of post-Soviet Armenia. Bearing in mind the opinion of Anselm L. Strauss (1961), who claims that there is a tendency to stereotype cities when talking about them, numerous researchers have remarked that such stereotype creation is the reason that changes are not reflected in places' images (Graber, 1989; Elizur, 1994; Avraham, 2000).

However, according to the interviewees, since 2000 central Yerevan has been transformed into a vast construction site, with cranes erected all over the Kentron district. Officially, the scores of multi-story buildings are part of large-scale urban planning. Several researchers have focused on the notion of the cultural economy of capitalist cities by emphasising that it targets the commercialisation of historical heritage and large-scale public investment promoting collective cultural consumption due to urban renovation (Wynne, 1992; Bassett, 1993; Moulinier, 1996; Scott, 1997; Ntaras, 2001). Furthermore, according to Sasha Tsenkova (2011), planners and policy makers directly apply western European development models to transition countries. Especially concerning the former Soviet countries, this phenomenon is explained by several researchers that have developed the opinion that the political traditions of former Soviet countries have a strong post-communist legacy regarding the creation of a different relationship between state and society (for further analysis, see also Chirot, 1989; Schöpflin, 1993; Janos, 2000; Berend, 2003; Kulcsar \& Domokos, 2005). According to Kulcsar and Domokos (2005), this difference is a result of the fact that the local elites were always competing with other localities for redistribution of resources in order to assert and maintain their local power during communism.

Furthermore, in a global context, the contemporary postmodern capitalist state of disciplines has constructed a network in which cities are invited to affect their own virtual landscape media image by public relations and promotional efforts, even if it is not possible to control the socio-cultural context, the editorial decisions or most of their socio-cultural identities (Avraham, 2000). Furthermore, the target audience in a contemporary globalised network is the tourists, the upper/new middle class (international or/and local) and businesses. The political orientation intends to create a new metropolitan lifestyle of middle and upper income groups by completing the need for phantasmic seduction (Žižek, 1989, cited in Kaika, 2011: 985) through architectural production according to Kaika's (2011) research. Nevertheless, according to Kulcsar and Domokos (2005) and some of the interviewees, in post-communism social costs are well hidden and that is why the development took place in a very supportive environment. It is no accident that the interviewees associated the notion of development with technology (Rus. технология), growth (Rus. pocm) and height (Rus. выcoma) without focusing on the restoration of social values.

On the other hand, according to Kevin R. Cox (1995) the "local economic development policies to attract business in a competitive environment are likely to sustain and even support the inequalities in the distribution of benefits". That is why the two major socio-cultural identities named as "cosmopolitanism" and "exclusionism" by Konstantinos Ntaras (2001) may become apparent in Yerevan and menace its cultural landscape. The dominant factor for upper-income groups to create a lifestyle based on the new consumption patterns is income level, and in this case the real danger is that this virtual landscape could be transformed with the passing of time into a new 
cultural landscape, destroying the socio-cultural identity of the place. The degree to which this virtual landscape could be assimilated depends on the socio-economic future of the country. If this new metropolitan lifestyle dominates, the past will be eliminated from the landscape image of the city.

\section{This new marketing orientation affects the "cultural landscape" of a new metropolis in a global network by reinventing the icon}

The last ambitious project of the Municipality of Yerevan was the announcement of an Open International Competition. This competition was organised and promoted by a multinational corporation, a symbol of luxury car manufacturing, in conjunction with several ministries of the Republic of Armenia and in accordance with UNESCO regulations and with the approval of the International Union of Architects (IUA). The goal of the competition - as announced in its program and conditions - was to "realize a new and original urban development project that should be both architecturally and functionally integrated" into the surrounding cityscape. This "original urban development" was to comprise a luxury hotel and a business centre. In every case, the design proposal had to appear as a "dominant architectural solution from all points in the city" in order to constitute the new iconic symbol of Yerevan. Due to its importance for the organisers, this multifunctional complex was to be realised as a major civic centre with main city streets oriented towards it as a concluding element. In addition, the organisers forced the design concept to locate the hotel in the southern part of the territory, with a maximum number of rooms offering a direct view of the city. Appearing as a dominant architectural element due to its location and volume, the hotel building was to be the most "striking element of the construction", according to the organising committee. In addition, a residential building oriented to the south with the highest quality apartments possessing all features of comfortable accommodation was to be designed according to the design assignment. Bearing in mind that the construction territory is a rising 4.4 ha platform surrounded by main streets with a panoramic view of the city centre and a view of Biblical Mount Ararat to the south, we understand the importance and the magnitude of such a huge landscape creation (Figure 3).

At the marketing level, the announcement of this competition demonstrates the effort to create an image of economic regeneration. The conjunction of the IUA with two ministries, UNESCO approval for the content of the competition, the entire organisation and the call for projects at an international level constitutes free international publicity with cultural perspectives in the landscape image of the city. Abstract words and expressions with a strong sense such as a "striking element of the construction" and "dominant architectural solution from all points in the city" or "multifunctional complex" demonstrate the nature of a huge manufactured landscape (Mavromatidis, 2010). Yerevan is located in an earthquake-sensitive region and the seismic stability of the construction must be able to endure 9.0 on the Richter scale. The luxury hotel building must also be $101 \mathrm{~m}$ high. This demonstrates that this urban and architectural operation should create a built landscape that is an iconic symbol of the economic and technical

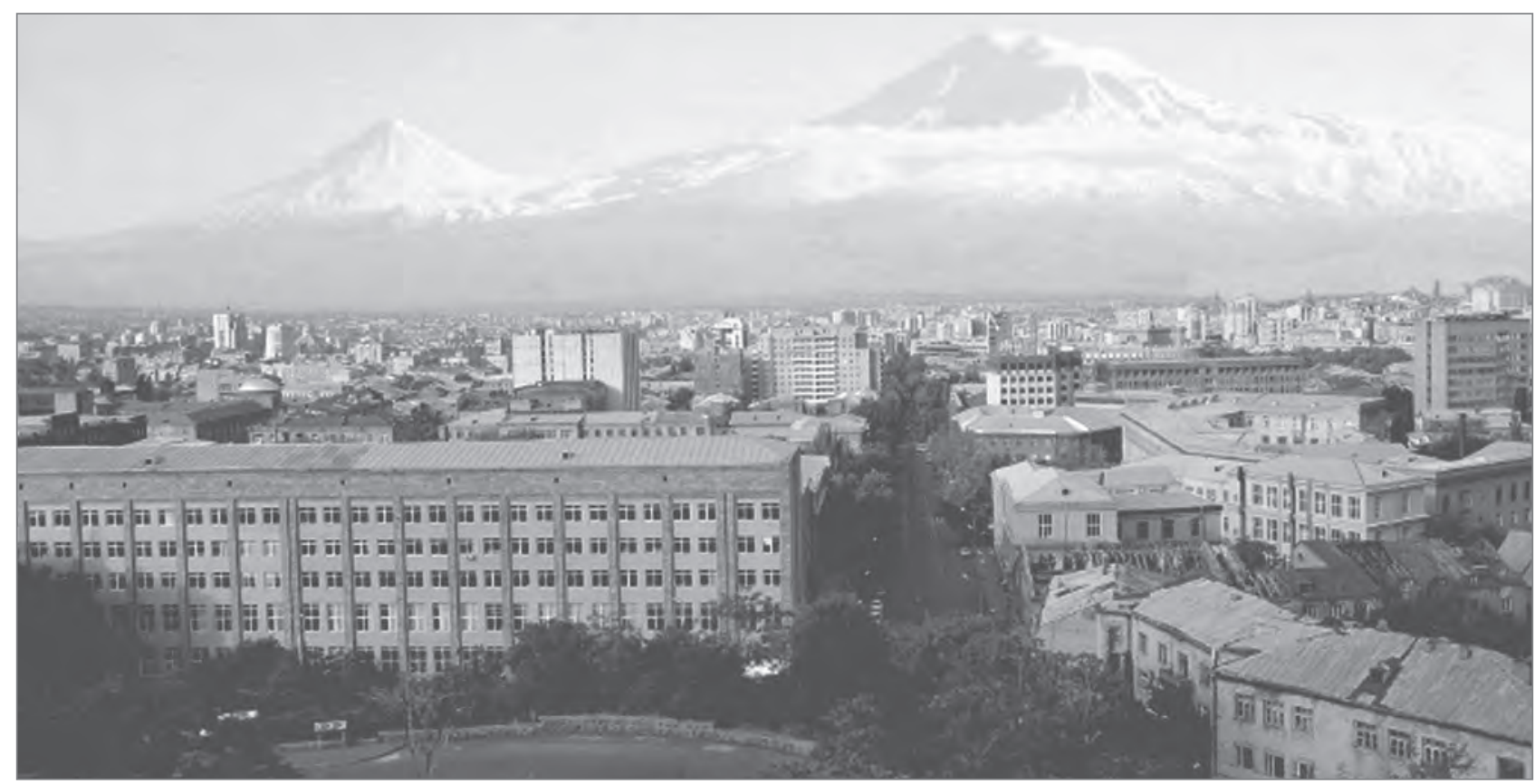

Figure 3: View from project site to Mount Ararat to the south (photo: Hanna Mangasarian) 
strength of Armenia. However, does the contradiction of an earthquake-resistant and strong tall building create the image of a high-tech contemporary megacity in the imagination as a symbol of strength? To answer to this question, we have to use the notion of the Big Other (Žižek, 1989), which is explained in the following sections.

\section{Construction of a network of doubts dealing with the paradox of authority in order to reinvent the icon}

After the brief analyses of the problem above, we imagine that we are invited to participate in this competition as individual architects by exploring the various dilemmas that are imposed by the competition's guidelines and the socio-cultural reality of Armenia. In this work the notion of doubt is seen as a Chomskyan primitive power that gives birth to every idea or concept in order to form Castoriadis' radical imaginary of each society. On the other hand, there is the Foucauldian state of disciplines established by economic and political factors in order to control the non-economic factors of social reality. To explain through which psychological mechanism the Foucauldian state of disciplines of each historical period can transform or delete the intellectual dimension of doubt, we employ Lacan's Big Other structure (for a detailed analysis, see also Žižek 1989, 1998). Today few will deny that the notion of doubt has a negative intellectual dimension because of the cultural status of societies today, in which a person should be certain in order to prove his self-confidence to others, and this involves the Big Other's knowledge. ${ }^{[4]}$ Empirical material has confirmed the negative notion of doubt in the social imaginary, whereas many of the interviewees associated doubt with uncertainty (Rus. неуверенность), danger (Rus. опасность), fear about the possibility of not finding a job (Rus. нaümu paбomy) or a psychological mechanism that gives the person the opportunity to survive (Rus. возможность выљжить). ${ }^{[5]}$ Because architects are part of society, they entered this game and eliminated the procedure of doubting by presenting definitive projects that are symbols of power and certainty. This paper tries to employ this dipole of doubt versus state of disciplines during our personal experimentation on a real architectural practice that began with the analysis of objective spatial data and ended with a proposal for an architectural composition that, for the first time in its existence, is placed in a continuous doubting procedure regarding what is correct or not. The main purpose is to reinvent the subjective dimension of the architect using doubt as the main tool.

However, in this case study the design assignment claim of a statement cannot be authorised by means of its primordial context and content. What is then the foundation of its hidden authority expressed through the form of an international architectural competition? In order to give a psychological explication, we employ Kierkegaard's reflection, whereby "the ultimate and only support of a statement of authority is its own act of enunciation" (Kierkegaard, 1962: 100). In our case, the framework of the competition consists of an authority that is backed up by an immediate physical compulsion because what the architect is dealing with is not an authority proper but simply an agency of brute powerless force (Žižek, 1992) expressed through certain competition rules. However, in Slavoj Žižek's opinion (1992) the authority has a paradoxical dimension, so in our case study the design assignment is a very certain call that cannot force the architect into anything and yet, by a kind of unconscious compulsion, the architect feels obliged to follow it unconditionally because this state of disciplines has authority and not because its content is correct, wise and profound.

This is how the architect unconsciously passes from subjectivity to objectivity by eliminating his doubts following the directives of the authority. Therewith, after the entire analysis presented in the previous sections of this paper, why is there always the danger of blindly following the design assignment without trying to construct a network of doubts in order to contest its real dimension with arguments ${ }^{[6]}$ To offer an explanation of this situation, to our knowledge there is no other answer than Žižek's analysis of the Lacanian Big Other structure, whereby the Big Other does not have the requested socially recognised knowledge to doubt the state of disciplines established by the authority (in this case, the design assignment of the competition ${ }^{[7]}$ and for this reason he blindly follows it.

However, even if it is clear that the individual architect himself does not have the power to decide on the urban orientation of the decision centres, he does have the power to try to transform the economic directives and orientations into potential cultural landscape creations by doubting. The primordial question according to the theoretical and field analysis is articulated in the need to "consider the potential of local communities in urban governance in order to deal with social inequalities" (Erkip, 2000). Therewith from the interviews we understood that the forced egalitarism imposed by the fundamental logic of the communist period has as its post-communist legacy the fact that people are much more interested in expressing their formerly suppressed individualism. Consequently, because of the factors mentioned above, a community feeling is perceived as a negative notion by the Big Other structure of a person that lived during the communist era within a communist state of disciplines.

In contrast, for us (the acting individual architects) that live and think inside the framework of capitalist individualism, 

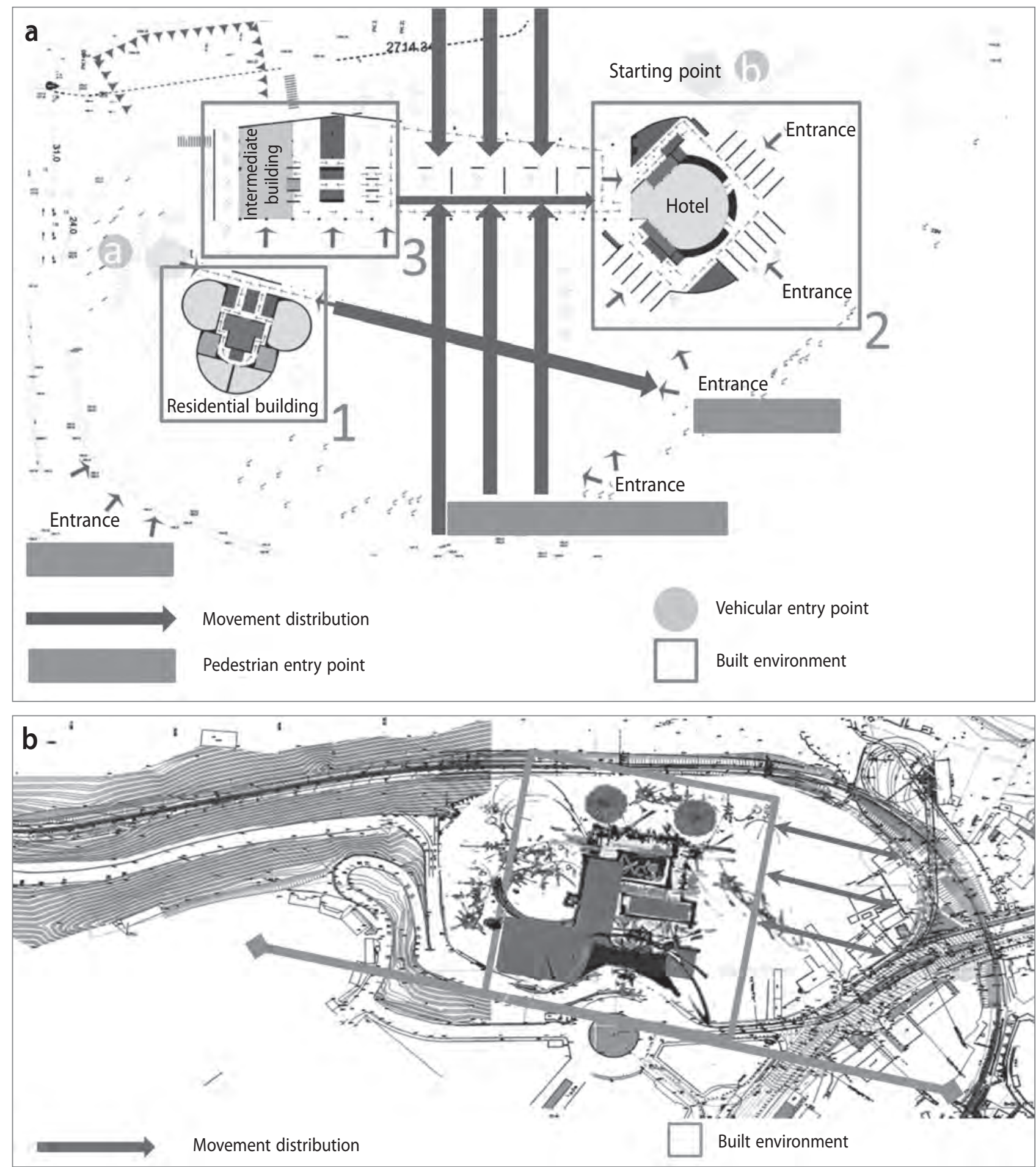

Figure 4: a) [Approved intention] Movement distribution in the territory. The movement of visitors is intended to become a spectacle on its own by creating a "transparent landscape"; b) [Rejected intention] If someone blindly follows the competition guidelines, he should put the built environment in the centre of the territory. Hence the hotel complex will disturb a uniform and transparent movement distribution. The global element represented in the hotel's iconic existence would be the most striking element and, being in the centre of the territory, it will be perceived as a barrier in the imaginary of the city (illustrations: Lazaros E. Mavromatidis).

the community feeling is perceived as a purely positive notion by our personal Big Other structure. Furthermore, being part of a capitalist society in crisis, our radical imaginary is moving towards a community sense of aesthetic production. However, for a person that lived inside an imposed commu- nity context, her or his radical imaginary is inseparable from individual aesthetic patterns. Perhaps the first step in reaching equilibrium in design is to assimilate the global element (luxury hotel) with the local dimension in the same territory by trying to transform the territory into space. Perhaps in this 


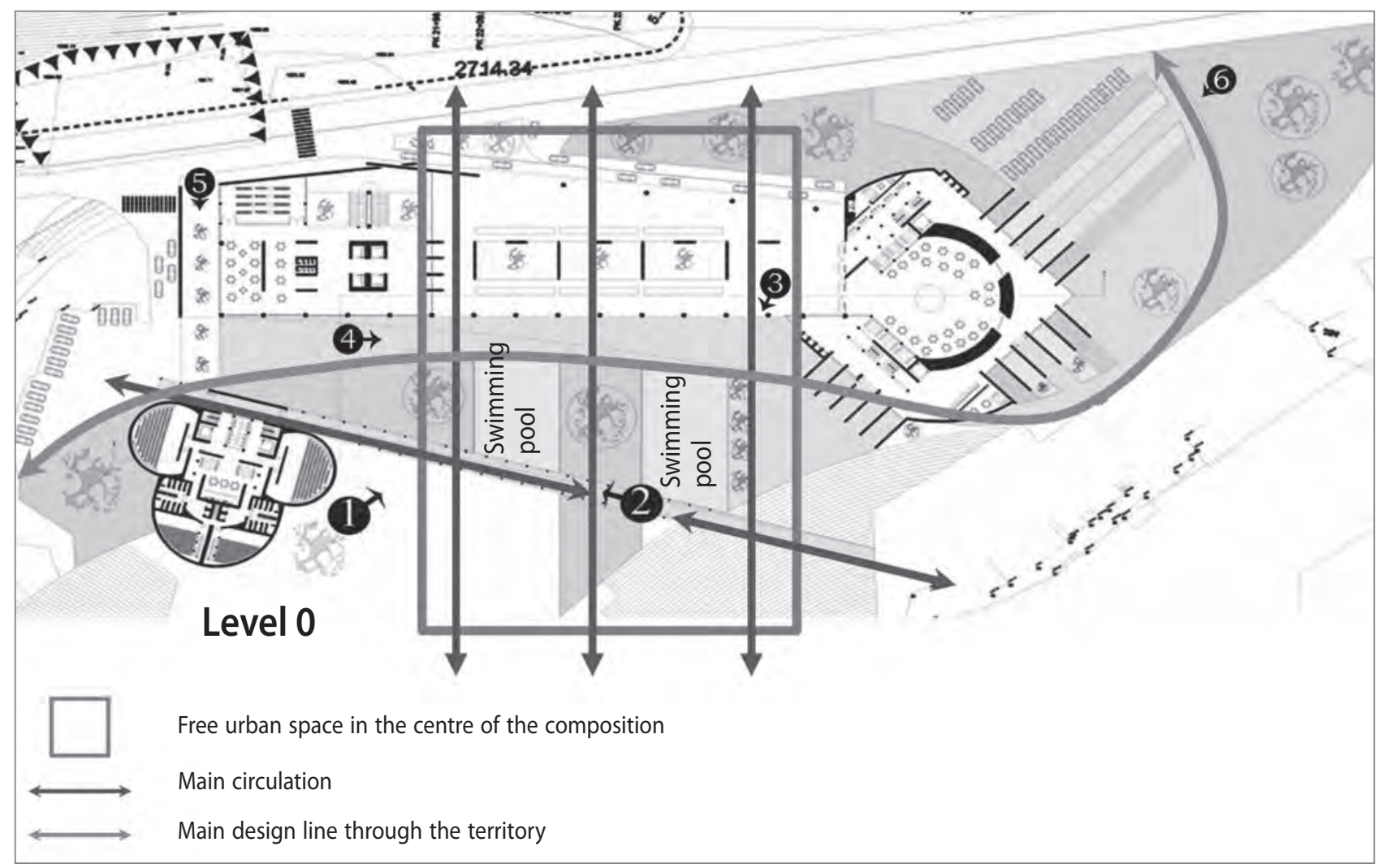

Figure 5: The main aim of this landscape proposition is to reunite a desert site in the limits of Yerevan with the city's urban traces, by creating a dialogue between the interior and exterior elements of the landscape, creating interaction and aesthetic stimulation between local and international visitors (illustration: Lazaros E. Mavromatidis).
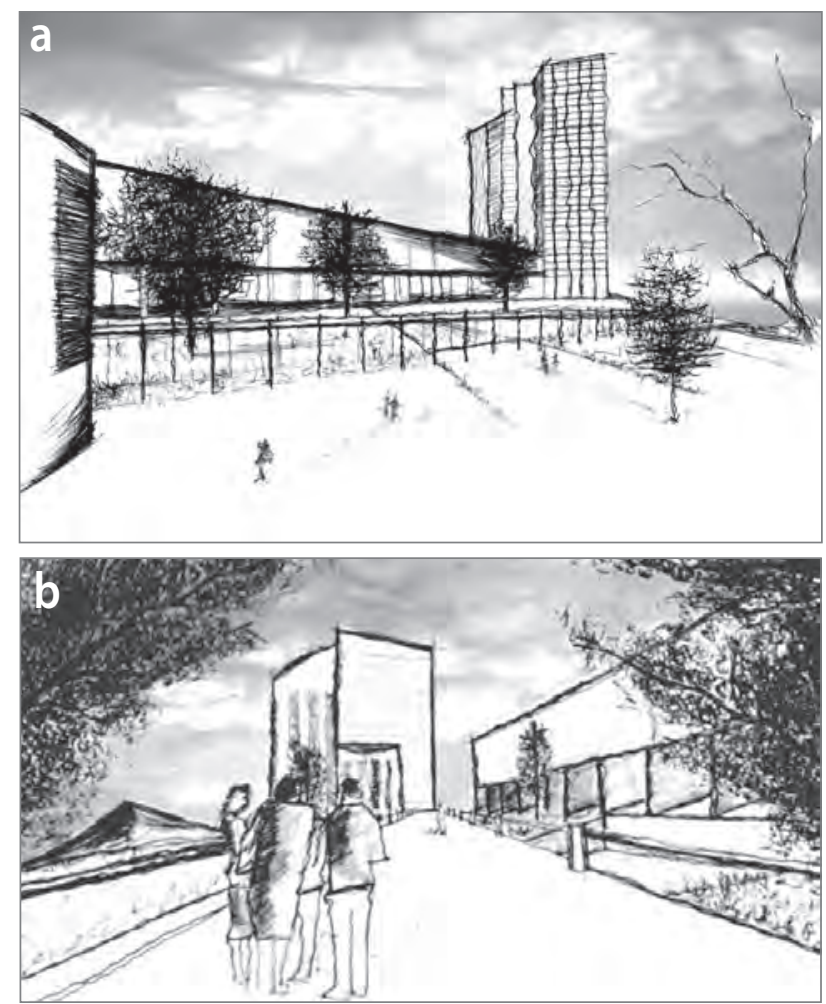

Figure 6: View of the potential landscape impression: a) Standing at point 1 of Figure 5 ; b) Standing at point 2 of Figure 5 (illustrations: Lazaros E. Mavromatidis). context of doubts the only solution is to follow Vaiou's opinion and create a "knife-edge" project "built upon in-betweenness: in-between local and international, outside and within, isolation and contact, east and west, female and male, interest and indifference" (Vaiou, 2004: 531).

\section{Towards a proposition: Landscape's articulation and basic elements of creation}

In the composition that resulted from the analysis, the landscape is articulated into three parts that are designed around the specific needs of each part of the program and the personal objective of following a policy of population mixture in order to create a transparent space open to residents as well as to international or domestic visitors. The choice to follow a strategy of population mixture is an experimental intention created by the personal need to contest the strict state of disciplines of the competition, in which non-economic factors are neglected. The three main parts of the composition comprise the hotel building, a residential complex including a library, cinemas and theatres, and an intermediate building: a business centre with exhibition and conference halls and a cultural orientation. According to our proposal, the residential building is intended 

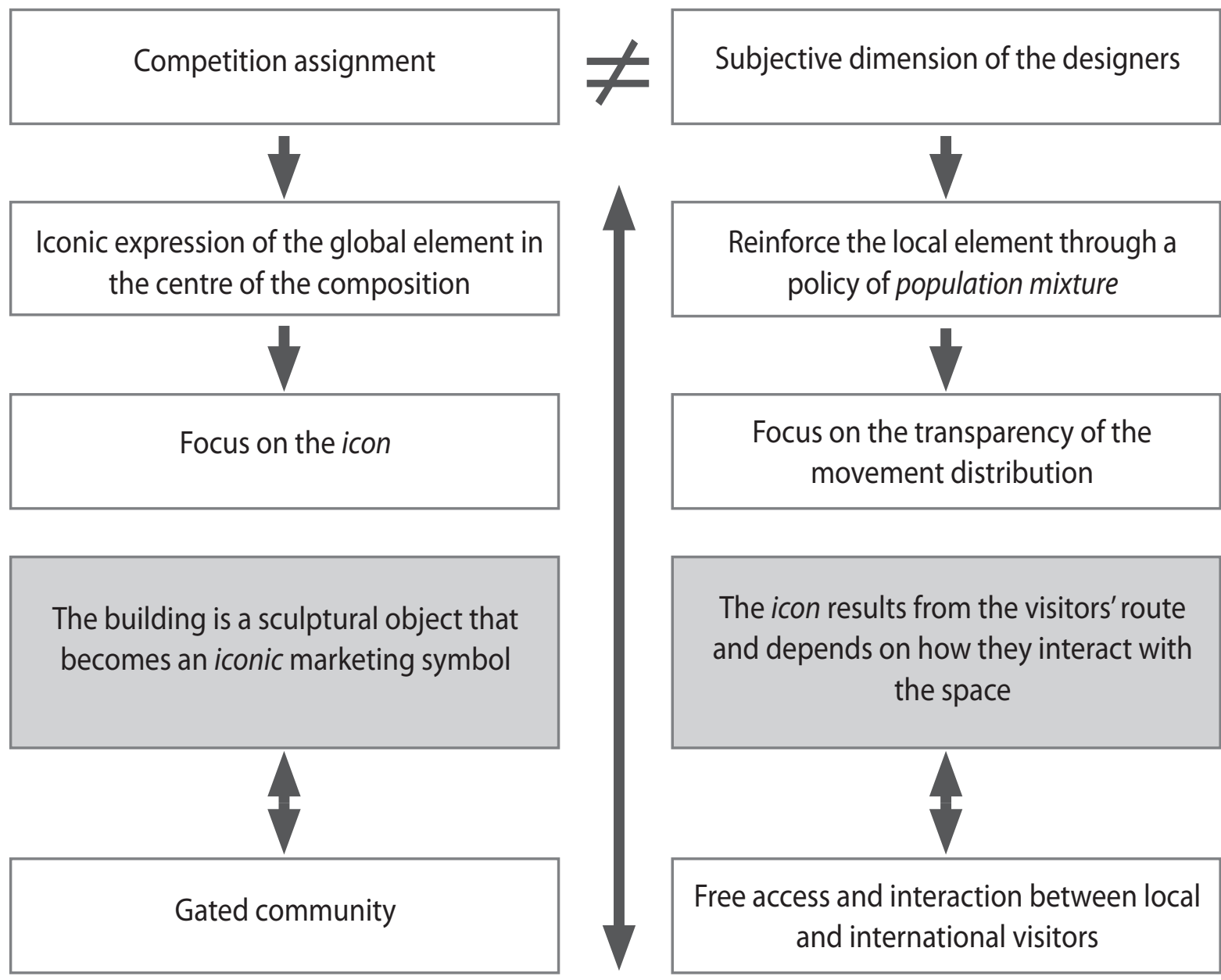

Figure 7: Schematic representation of the main conceptual difference between the authors' subjective dimension and the competition's assignment (illustration: Lazaros E. Mavromatidis).

to become a multi-dimensional facility for the city, for artists, researchers, and students alike, and it should be open to every resident of Yerevan. Following the policy of population mixture, we propose transforming $50 \%$ of the apartments into rent-controlled residences in order to attain a kind of social equilibrium in the territory and enhance its social accessibility.

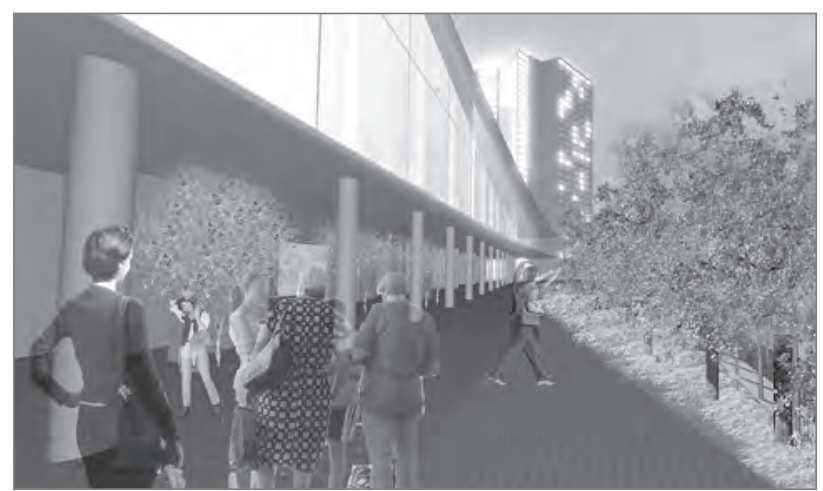

Figure 8: Experiential aspect of the proposal standing at point 3 of Figure 5. The hotel building is in the background (illustration: Asimina Mavromatidi).
Regarding movement distribution into the territory, a main circulation route narrates the spatial experience from the city street into the complex's world. According to Kaika (2010) "the city continues to be lived at the street level where the buildings hit the ground" and for that reason there is intense attention in order to preserve the territory's connection with

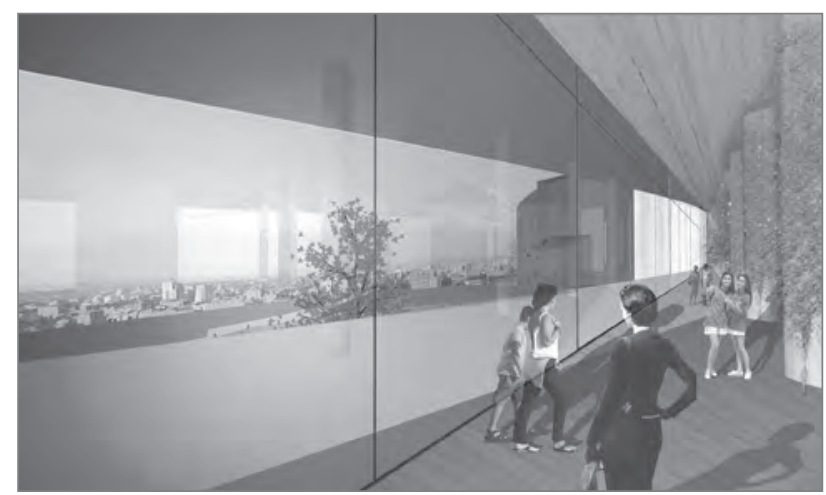

Figure 9: Experiential aspect of the proposal standing at point 4 of Figure 5. View of Mount Ararat from the interior of the intermediate building, which can be accessed by everyone (illustration: Asimina Mavromatidi). 


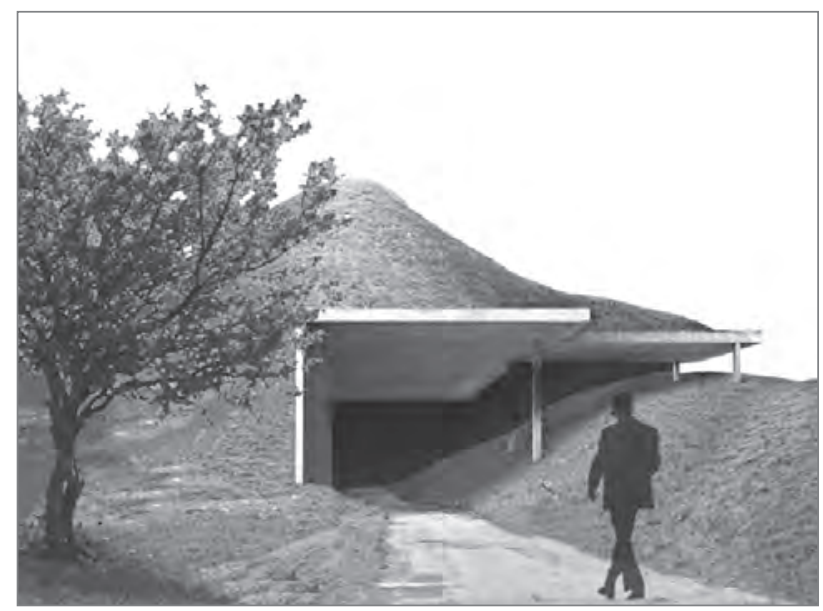

Figure 10: Experiential aspect of the proposal standing at point 5 of Figure 5 . The visitor's route is not a single linear sequence, and so the visitor must discover many alternative entrances that serve to insert him into the territory (illustration: Asimina Mavromatidi).

the city's space (Figure 4a). Considering movement distribution as the most important element of conception, we can reject solutions that arise from the intention of blindly following the competition assignment and putting the hotel complex in the centre of the territory (Figure $4 \mathrm{~b}$ ). For this reason, the main design value is based on the theoretical position that the new landscape item should be designed in accordance with the particular characteristics of the specific place, simultaneously linked to the aim of achieving visual harmony and continuity in the given urban tissue (Abel, 1997). In this direction, the visitor's base is a circular atrium at the level of the hotel complex (open to everybody) and a free-access library belonging to the residential building. Movement in and through a complex with various facilities is seen as an important aspect for architecture and landscaping as well (Figure 5). In landscape terms, great excitement is intended to be generated from the fact that the concept and the topography invite local and international visitors to interact while entering the building at mid-level (Figure 6).

Accordingly, the main purpose of this composition is to reunite the internal part of the building with the city's circulation, somewhat like an outside but inside view resulting from carving out a series of interior spaces and routes (Figure 7). In this interior landscape, aesthetic compositional rules were not blindly followed, and the functional logic of the interior route and organisation is revealed by the elevations. Each solid was created from the structural grid and from notional envelopes defined by functional zoning regulations in order to render each part of the complex accessible to everybody.

Thus, the underlying logic of the building is expressed by the facades and presents the aspects of a structure that is resistant to earthquakes at 9.0 on the Richter scale. In this case, the

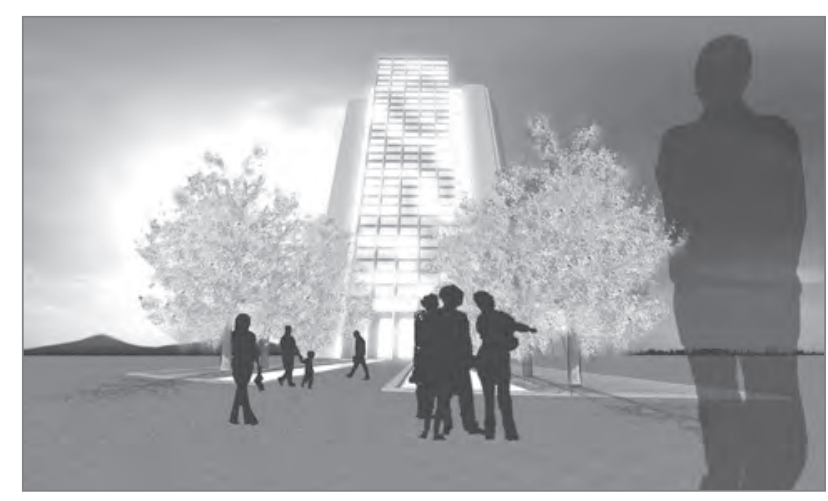

Figure 11: Experiential aspect of the proposal standing at point 6 of Figure 5. The constraints of the site, the geology, the design assignment and the socio-cultural non-economic elements of this city are such that they impose a minimal, simple external model. However the building's reduced iconic presence lets the visitor discover the view from every point of the territory. To the left the visitor can see Mount Ararat even if he is standing in front of a $101 \mathrm{~m}$ thick-walled hotel building (illustration: Asimina Mavromatidi).

structure is foundational and reveals a newly defined landscape element for seismic stability reasons. The constructive and functional system of the complex is intended to be simple and comprises repetitive cells in a regular concrete structure. In the centre of the entire composition, the intermediate building - a business centre - is equipped with conference and exhibition halls. The base floats on piers and is based on a network of columns so as to resist earthquakes of 9.0 on the Richter scale (Figure 8). This level contains the entrance, temporary exhibition spaces and all the support facilities of a cultural centre open to all citizens of the country (Figure 9).

\section{Conclusions: Requiem for a dream, or a wish to create a heterotopia}

In this case study, the international business centre in Yerevan, including a hotel, is not conceived of as a sculptural object, but as an interior route or city, in order to guide people through a new and simple potential cultural landscape, with local and global characteristics. The exterior form of each building is an expressive form derived from its interior dimensions. Moreover, the route is not a single linear sequence with a fixed beginning, middle and end, but a multiple sequence that can be accessed or left from many different points, in a constant dialogue with the natural elements of the landscape and expressing doubt on a potential imposed deterministic level of circulation (Figure 10).

According to Foucault, spaces that exist in a contradictory way and produce social relations that debate and contest the existing social framework and reality could form a heterotopia (Foucault, 1993). This new landscape in Yerevan is not proposed as a unitary totality, but is oriented to become a 
heterotopia. It combines three distinct types with different social orientations on its site: a dominant architectural element (hotel complex), which is imposed from the design assignment, a symbolic factory-type intermediate building equipped with many cultural spaces and a residential building including socio-cultural territories. In order to form a heterotopia, it should be open and accessible to everybody that wants to visit its temporary exhibitions and conferences (the balcony of the complex), and that is why the new secondary multifunctional building is equipped with variable spaces and interspaces (a residential building including a library, a cinema, a restaurant and theatres).

In this case study, architecture is considered to be a strategy of urban and landscape creation and not so much a formalistic architecture. The constraints of the site, the geology, the design assignment and the functional zoning regulations including the socio-cultural non-economic elements of this city impose a minimal, simple external model. Otherwise, studying traditional Armenian architecture, anybody can understand that simplicity is fundamentally minimal in the Armenian philosophy of creation because it originates in an earthquake-prone region and tends to be conceived with this hazard in mind. Armenian buildings tend to be rather low-slung and thick-walled in design (Figure 11). As a result, traditional Armenian architecture employs a form of concrete to produce sturdy minimalist buildings.

The main objective is to provide an opportunity for the socio-cultural identities of this city to decide whether this newborn territory will age gracefully in the city's consciousness and be assimilated into it to form a real cultural landscape, at the same time transforming the territory into space and place.

According to David L. Prytherch's (2003) research on policy making, the individual architect does not have the power to navigate a complex political climate in which the land to be urbanised for a city's future (in this case Yerevan's future) is also a symbol of its past. However he can employ a set of social practices that are oriented not merely toward economic production but also toward non-economic factors such as cultural tradition and regional identity in order to reform the future scale of urban life and reinvent the iconic dimension passing through a continuous doubt. The policy of population mixture proposed for the residential building, the use of materials such as concrete and metal in order to accomplish the design of such a huge creation with simplicity, and the multiple creation of open cultural spaces combined with a clear and transparent exterior and interior circulation in this new territory with no starting points and endpoints are intentions that try to create a doubt in a formalistic assumption of architecture.
In order to reinvent its iconic dimension, the space's accessibility to socio-cultural identities is employed as a main source of inspiration that has the potential to build on what is defined by Castoriadis' radical imaginary. Hence, as we understand the main point of the alternative presented here, the icon results from the visitor's route and depends on how he will interact with the constructed space. For this reason, this solution offers a variety of free spaces in order to help the visitors feel free and transform the space according to their preferences and habits. The building is not a sculptural object; however, the free space has a sculptural dimension because the users can change the geometry, occupation mode and scale of their personal interventions. Even if it is a virtual study that is not realised, the approach presented above could have real consequences at a concrete and not theoretical level, only if the decision centres allow it to exist. Therefore, the main objective of the project discussed above is to define, negotiate and start the discussion on radical architectural approaches to landscape creation in today's megacities within a strict capitalist context rather than proposing a correct and definitive way of seeing and conceiving the icon of future reality.

Lazaros Elias Mavromatidis

Ecole Nationale Supérieure d'architecture de Lyon, Laboratoire MAP-ARIA UMR CNRS-MCC 3495, Lyon, France

E-mail: lazarosmavr@hotmail.com

\section{Asimina Mavromatidi}

National Technical University of Athens, Faculty of Architecture, Athens, Greece

E-mail:semimavr@gmail.com

\section{Notes}

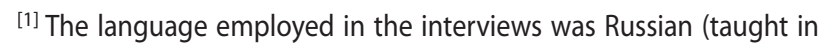
Armenian schools during the Soviet era and still spoken fluently in the country, today the country's second official language). The interviews were conducted from 1 February 2011 to 25 August 2011. They were translated by Anna Bykalyuk.

${ }^{[2]}$ For details, see the discussion in English and French between Michel Foucault and Noam Chomsky filmed for the television of Netherlands at the Eindhoven University of Technology (Chomsky \& Foucault, 1971).

[3] To further understand how this mechanism of human psychology works, one can take George Clooney as an example, who is the main character in Anton Corbijn's film The American, adapted for the screen from the novel $A$ Very Private Gentleman by Martin Booth. In the aftermath of a job turned fiasco, an American hitman named Jack (George Clooney) retreats to the Italian countryside. Not eager to tempt fate again, he takes as his last job assembling a weapon for a mysterious woman named Mathilde. During this uncharacteristically peaceful interlude, Jack starts an affair with Clara, a pretty local prostitute. Tormented by suspicions that someone is about to kill him, he suspects Clara of informing his enemies about his movements. He persists in his indecision by also suspecting Mathilde, the woman for whom he is assembling the weapon. In the final scene he realises that his suspicions about Mathilde were correct because we 
discover that he was assembling for her the gun that was intended to kill him; however Clara was totally innocent. At this time, according to Žižek's interpretation of Lacan's theory, by finding the answer to his suspicions the hero of the movie loses his status as an acting subject and he is transformed into an object. Today the architect looks like Jack in Corbijn's film when he has just realised that he is working for official and unofficial institutions, and at the same time losing his subjective decisional dimension.

${ }^{[4]}$ In this short contribution essentially written as a debate, I cannot engage in a pure analysis of psychological structures in terms of original ideas and detailed analysis. However, in order to understand how the notion of doubt has a negative value in a contemporary capitalist organisational system, recall how the markets reacted in 2010, when the prime minister of Greece expressed his doubt about Greece's ability to pay off its debt. Furthermore Hollywood and publicity played their role all these years in the unconscious control of the Big Other. For example, we cannot imagine Marlon Brando or Brad Pitt as heroes incarnate full of doubts and at the same time attractive to women. Society based on male patterns to enrich its sense of power is guided to give a negative dimension and definition to doubt, and a positive one to certitude.

[5] The fact that the notion of doubt has a negative image in the imaginations of people that constructed their personalities within a communist organisational system is also explained by the fact that Soviet societies were based on the idea of a person strong enough to be certain of everything. However, in wider Russian culture before the communist era, doubt was a motivating element of reflection; for example, in Anton Chekhov's writings.

${ }^{[6]}$ It is informative to look at architects' writings concerning composition, available at many internet sites. There is no reflection developed on this multicomplex subject of architectural-landscape creation and its socio-cultural impact; however, there are numerous references to the aesthetic formalistic representation of the iconic architectural item and the territorial division into VIP spaces and common spaces, ensuring that the entire complex will be gated in order to be isolated from the city, preserving at the same time its luxury character. The contradiction is that, even if the complex is sufficiently gated, at the same time the creators of such projects claim that the entire composition is integrated in a harmonic way with the urban fabric.

[7] For further development and analysis, see also Žižek (1992: 98100).

\section{Acknowledgements}

First of all, the authors are grateful to Maria Kaika for supporting this work during the early stages, as well as for her constructive comments on previous draft versions and for her continuous availability. The anonymous reviewers are thanked for their comments and their constructive suggestions. Both authors also gratefully acknowledge Damianos Aronidis, Andrea Kindinis and Anna Bykalyuk for their faith in this project and their help in accomplishing and evaluating it in more detail. Hanna Mangasarian is specially thanked for providing permission to use her photos. Lazaros Mavromatidis would like to dedicate this work to Aniouta for her faith on him and her continuous encouragement. Both authors would like to thank Elias, Stamatina, Assimina and Pinelopi for their presence and Nikos for his virtual encouragement, even if we know that he may perhaps never read these lines. Finally, we would also like to express a memoriam and goodbye to the poet and friend Argyris Hionis.

\section{References}

Abel, C. (1997) Architecture and identity: Towards a global eco-culture. Oxford, Architectural Press.

Avraham, E. (2000) Cities and their news media images. Cities, 17(5), pp. 363-370. DOI: 10.1016/S0264-2751(00)00032-9

Bassett, K. (1993) Urban cultural strategies and urban cultural regeneration: A case study and critique. Environment and Planning A, 25(12), pp. 1773-1788. DOI: 10.1068/a251773

Berend, I. T. (1986) The historical evolution of Eastern Europe as a region. International Organization, 40(2), pp. 329-336. DOI: 10.1017/ S0020818300027168

Brown, B. B. \& Perkins, D. D. (1992) Disruptions in place attachment. In: Altman, I. \& Low, S. (eds.) Place attachment, pp. 279-304. New York, Plenum. DOI: 10.1007/978-1-4684-8753-4_13

Canter, D. (1977) The psychology of place. London, The Architectural Press.

Castells, M. (1977) The urban question: A Marxist approach. Cambridge, MA, MIT Press.

Castells, M. (1978) City, class, and power. London, Macmillan.

Castells, M. (1996) The rise of the network society. London, Blackwell.

Castoriadis C. (1987) The imaginary institution of society. Cambridge, Polity.

Chirot, D. (ed.) (1989) The origins of backwardness in Eastern Europe. Berkeley, University of California Press.

Chomsky N. \& Foucault M. (1971) Human nature: Justice versus power. The Chomsky-Foucault debate. Available at: http://www.chomsky.info (accessed 1 Apr. 2012).

Cox, K. R. (1995) Globalisation, competition and the politics of local economic development. Urban Studies, 32(2), pp. 213-224. DOI: 10.1080/00420989550013059

Davidoff, P. (1965) Advocacy and pluralism in planning. Journal of the American Institute of Planning, 31(6), pp. 331-338. DOI: 10.1080/01944366508978187

Elizur, J. (1994) Israel and the US: Images of flawed paradise. Paper presented at the American-Israeli Relations and the 'New World Order' Conference, 8 June 1990, Jerusalem, Israel. Typescript.

Erkip, F. (2000) Global transformations versus local dynamics in Istanbul: Planning in a fragment metropolis. Cities, 17(5), pp. 371-377. DOI: 10.1016/S0264-2751(00)00033-0

Fainstein, N. I. \& Fainstein S. S. (1985) Is state planning necessary for capital? The US case. International Journal of Urban and Regional Research, 9(4), pp. 485-507. DOI: 10.1111/j.1468-2427.1985.tb00443.x

Foucault, M. (1993) Of other spaces: Utopias and heterotopias. In: Ocman, J. (ed.) Architecture culture 1943-1968: A documentary anthology, pp. 420-426. New York, Columbia Books of Architecture/Rizzoli.

Gans, H. J. (1979) Deciding what's news. New York, Random House.

Graber, D.A. (1989) Flashlight coverage: state news on national broadcasts. American Politics Quarterly, 17(3), pp. 277-290. DOI: 10.1177/1532673X8901700303

Hadjimichalis, C. (2006) Non-economic factors in economic geography and in 'new regionalism': A sympathetic critique. International Journal of Urban and Regional Research, 30(3), pp. 690-704. DOI: 10.1111/j.1468$2427.2006 .00683 x$ 
Hadjimichalis, C. \& Hudson R. (2006) Networks, Regional Development and Democratic Control. International Journal of Urban and Regional Research, 30(4), pp. 858-872. DOI: 10.1111/j.1468-2427.2006.00687.x

Harlow, M. (1977) Captive cities. New York, John Wiley.

Harvey, D. (1978): Planning the ideology of planning. In: Burchell, R., \& Sternlieb, G. (eds.): Planning theory in the 1980s, pp. 213-233. New Brunswick, CUPR.

Hionis, A. (2010) Everything I describe it describes me; room poetry. Athens, Gavriilides editions.

Holton, R. J. (1984) Cities and the transitions to capitalism and socialism. International Journal of Urban and Regional Research, 8(1), pp. 1337. DOI: 10.1111/j.1468-2427.1984.tb00411.x

Janos, A. C. (2000) East central Europe in the modern world: The politics of borderlands from pre- to postcommunism. Palo Alto, Stanford University Press.

Kaika, M. (2010) Architecture and crisis: Re-inventing the icon, re-imag(in)ing London and re-branding the city. Transactions of the Institute of British Geographers, 35(4), pp. 453-474. DOI: j.1475-5661.2010.00398.x

Kaika, M. (2011) Autistic architecture: The fall of the icon and the rise of the serial object of architecture. Environment and Planning D: Society and Space, 39 (6), pp. 968-992. DOI: 10.1068/d16110

Katsenelinboigen, A. (1990) The Soviet Union: Empire, nation and systems. New Brunswick, NJ, Transaction Publishers.

Kierkegaard, S. (1962) The present age. Of the difference between a genius and an apostle. New York, Harper Torchbooks.

Kulcsar, L. J. \& Domokos T. (2005) The post-socialist growth machine: The case of Hungary. International Journal of Urban and Regional Research, 29(3), pp. 550-563. DOI: 10.1111/j.1468-2427.2005.00605.x

Mavromatidis, L. (2010) Goutte d'Or: Inside the obscure of the metropolis. Itineraries in a neighborhood in the north of Paris. Geographies, 16(2), pp. 147-165.

Molnar, V. (2011) The cultural production of locality: Reclaiming the "European city" in post-wall Berlin. International Journal of Urban and Regional Research, 34(2), pp. 281-309. DOI: 10.1111/j.14682427.2010.00894.x

Molotch, H. (1996) LA as product: How design works in a regional economy. In: Scott, A. J. \& Soja, E. (eds.) The city: Los Angeles and urban theory at the end of the twentieth century, pp. 225-275. Berkeley, University of California Press,

Moulinier, P. (1996) L'état et les équipements culturels (1959-1995). Les Annales de la Recherche Urbaine, 70(1), pp. 140-147.

Ntaras, K. (2001) Urban cultural identities and globalization: A critical account. Culture \& Communication, 4(1), pp. 47-60.

Prytherch, D. L. (2003) Urban planning and a Europe transformed: The landscape politics of scale in Valencia. Cities, 20(6), pp. 421-428. DOI: 10.1016/j.cities.2003.08.008

Schöpflin, G. (1993) Politics in Eastern Europe, 1945-1992. Cambridge, Blackwell.

Scott, J. A. (1997) The cultural economy of cities. International Journal of Urban and Regional Research, 21(2), pp. 323-339. DOI: 10.1111/ j.1468-2427.00075

Sklair, L. (2005) The transnational capitalist class and contemporary architecture in globalizing cities. International Journal of Urban and Regional Research, 29(3), pp. 485-500. DOI: 10.1111/j.14682427.2005.00601.x
Stone, A. \& Harpham, E. (1982) The political economy of public policy. Beverly Hills, Sage.

Strauss, A. L. (1961) Image of the American city. New York, The Free Press.

Szelenyi I. (1984) Cities and the problem of the transition: Introduction and rejoinder. International Journal of Urban and Regional Research, 8(1), pp. 1-12. DOI: 10.1111/j.1468-2427.1984.tb00410.x

Tsenkova, S. (2011) Potovanje v neznano: strateško prostorsko načrtovanje $v$ posocialističnih mestih [Venturing into unknown territory: Strategic spatial planning in post-communist cities]. Urbani izziv, 22(1), pp. 5-21 [83-99]. DOI: 10.5379/urbani-izziv-en-2011-22-01-001

Vaiou, D. (2004) The contested and negotiated dominance of Anglophone geography in Greece. Geoforum, 35 (1), pp. 529-531. DOI: 10.1016/j.geoforum.2004.01.009

Wynne, D. (ed.) (1992) The culture industry. Aldershot, Avebury.

Žižek, S. (1989) The sublime object of ideology. London, Verso.

Žižek S. (1992) Enjoy your symptom! Jacques Lacan in Hollywood and out. London, Routledge.

Žižek S. (1998) Tarrying with the negative: Kant, Hegel and the critique of ideology. Durham, Duke University Press. 